\title{
Detection of $H$. pylori in Pediatric Patients' Stool Sample by Multiplex Urease PCR
}

\author{
Sinem Öktem-0kullu' ${ }^{1}$ iD , 0ğuz Can Işık ${ }^{2}$ (DD , Ayşe Sesin Kocagöz ${ }^{3}$ (DD , \\ Işın Akyar ${ }^{1,4}$ (iD
}

${ }^{1}$ Department Medical Microbiology, Faculty of Medicine, Acibadem Mehmet Ali Aydinlar University, Istanbul, Turkey

${ }^{2}$ Year III Medical Student, Acibadem Mehmet Ali Aydinlar University, Istanbul, Turkey

${ }^{3}$ Department of Infectious Diseases, Faculty of Medicine, Acibadem Mehmet Ali Aydinlar University, Istanbul, Turkey

${ }^{4}$ Acibadem Labmed Medical Laboratories, Istanbul, Turkey

\section{Sinem ÖKTEM-OKULLU}

Oğuz Can IŞIK

Ayşe Sesin KOCAGÖZ

Işın AKYAR

Correspondence: Sinem Öktem-0kullu Department Medical Microbiology, Faculty of Medicine, Acibadem Mehmet Ali Aydinlar University, Istanbul, Turkey

Phone: +905545874828

E-mail: sinem.oktem@acibadem.edu.tr

Received

Accepted : 23 September 2021

\section{ABSTRACT}

Background and objectives: This study aims to detect the H. pylori infection in pediatric patients'stool samples by using a multiplex urease PCR assay.

Materials and Methods: A retrospective analysis was performed and the $H$. pylori multiplex urease PCR test from a stool sample of 55 pediatric patients was evaluated from August 2017 to November 2018 compared with the H. pylori antigen test and histopathology.

Results: Thirty-six patients (65\%) were detected $H$. pylori-positive including nineteen boys (50\%) and nineteen girls $(50 \%)$ by $\mathrm{H}$. pylori multiplex urease PCR test. Fifteen (54\%) of the positive patients were in the $0-6$ age range, eighteen $(95 \%)$ in the $7-12$ age range, and three (38\%) in the $13-18$ age range. Comparison results with the histopathology and H. pylori antigen test were showed that the positive predictive value of the multiplex urease PCR test for the stool sample was $72.22 \%$. The test could detect a negative sample of $100 \%$.

Conclusions: Due to the results of this study it was showed that the prevalence of $H$. pylori infection is still high for pediatric patients. The multiplex urease PCR test for stool samples could be used in the clinic detection of $H$. pylori as a non-invasive method and easy to applicable method, but it needs to be evaluated for high specificity and sensitivity to detect accurate results.

Keywords: H. pylori, multiplex PCR, stool sample, pediatric patients

\section{Pediatrik Hastaların Dışkı Örneğinde H. pylori'nin Multipleks Üreaz PCR ile Saptanması \\ ÖZET}

Amaç: Bu çalışmada, çoklu üreaz PCR testi kullanılarak pediatrik hastaların dışkı örneklerinde $H$. pylori enfeksiyonunun saptanması amaçlanmıştır.

Yöntem: Retrospektif olarak yapılan bu çalışmada ve Ağustos 2017'den Kasım 2018'e kadar 55 pediatrik hasta dışkı örneğine uygulanan H. pylori çoklu üreaz PCR testi, H. pylori antijen testi ve histopatoloji test sonuçları karşılaştırılarak değerlendirilmiştir

Sonuçlar: H. pylori çoklu üreaz PCR testi ile on dokuz erkek (\% 50) ve on dokuz kız (\% 50) dahil 36 hastada (\% 65) $H$. pylori pozitif tespit edilmiştir. Pozitif hastaların $15^{\prime} \mathbf{i}$ (\% 54) $0-6$ yaş aralığında, $18^{\prime} \mathbf{i}$ (\% 95) 7-12 yaş aralığında ve üçü (\% 38) 13-18 yaş aralığında olduğu gösterilmiştir. Histopatoloji ve H. pylori antijen testi ile karşılaştırma sonuçları dışkı örneği için çoklu üreaz PCR testinin pozitif prediktif değerinin $\% 72.22$, negatif prediktif değerinin $\% 100$ olduğunu göstermiştir.

Tartışma: Yapılan bu çalışma sonuçları H. pylori enfeksiyonu prevalansının pediatrik hastalarda hala yüksek olduğunu gösterilmiştir. Dışkı örnekleri için çoklu üreaz PCR testi, özellikle pediatrik hasta grubunda $H$. pylori'nin klinik tespitinde non-invaziv ve kolay bir yöntem alternatifi olabilecektir. Ancak testin yüksek özgüllük ve duyarlıık açısından iyileştirilmesi için daha fazla örnek üzerinde denenmesi gerekmektedir.

Anahtar kelimeler: H. pylori, çoklu PZT, Dışkı örneği, pediatric hasta 
$\mathbf{H}$ elicobacter pylori (H. pylori) is a bacterial pathogen responsible for the most commonly found infection in the world's population. This pathogenic bacteria is the main cause of gastric diseases such as gastritis, peptic ulcer, and the World Health Organization (WHO) and The International Agency for Research on Cancer (IARC) have identified this bacterium as one of the major causative risk factors for stomach cancer (1). H. pylori infection is mainly acquired during adolescence and if it is not treated, it could persist lifelong. Nearly half of the World's population and about one-third of children worldwide are infected with this pathogenic bacteria. $H$. pylori infection prevalence rates are lower in developed countries when it is compared with the developing ones. The rate of $H$. pylori infection, epidemiology, clinical manifestation, and the applicability of diagnostic tests, antibiotic resistance, drug treatment options, and success rates for treatment differ significantly (2-3).

There are different methods to diagnose $H$. pylori infection and these methods are mainly classified as invasive and non-invasive. The invasive ones include endoscopy and biopsy for histologic examination, polymerase chain reaction $(\mathrm{PCR})$, and microbial culture. H. pylori antigens, antibodies, and DNA detection in saliva, urine, and stool specimen, are regarded as non-invasive tests. And also urea breath and serology tests are other non-invasive methods. The most frequently used test material is gastric biopsy specimens that are taken from the patients during the invasive methods. However, using stool and saliva samples is the most preferred sample to diagnose H. pylo$r i$ infection as a non-invasive test. Especially for pediatric patients' clinical management, test methods without any instrument introduction are becoming more important (4).

One of the sensitive, specific, and accurate molecular techniques to diagnose $H$. pylori infection is PCR. There are some target genes for the PCR to detect $H$. pylori infection. The stomach has a highly acidic environment. To live in the stomach this pathogenic bacteria produces a urease enzyme to neutralize the environment. The produced urease enzyme decreases the acidity of the stomach environment by generating ammonia and carbonate from urea. There are two subunits in the active site of this enzyme; urease $A$ and urease $B$. These active sites are coded by the urease $A$ (ureA) and urease $B$ (ureB) genes (5). In one of our articles, we explained that for the first time we developed a multiplex urease PCR for the accurate detection of $H$. pylori from the biopsy specimens taken from the stomach. Due to multiplex urease PCR assay and histopathological staining comparison results the sensitivity of histopathological staining that is one of the widely used methods for the detection of $\mathrm{H}$. pylori infection on the gastric biopsy specimens was lower than multiplex urease PCR assay. The accurate detection rate of our multiplex urease PCR is related to that it is possible to detect bacterial DNA that has just begun to colonize(6).

The aim of this retrospective study is to investigate the accurate $H$. pylori infection detection rate of a multiplex urease PCR assay from the pediatric patients' stool sample.

\section{MATERIALS AND METHODS}

\section{Patients}

55 pediatric patients aged from 0 to 18 years old were included in the study for retrospective analysis who applied to the Pediatric Gastroenterology Department of a state hospital because of gastric complaints (abdominal pain, epigastric, nausea, and vomiting) between 11.08.2017 and 27.12.2018.

\section{Stool Specimen}

Fresh stool samples were put into the special stool container with a lid and kept at $+4^{\circ} \mathrm{C}$ until DNA isolation.

\section{Multiplex Urease PCR}

Identification of $H$. pylori infection by using multiplex urease PCR, DNA was isolated from pediatric patients' stool samples by a commercial nucleic acid isolation kit (Quick gDNA, Zymo Research). Isolation experiments were done due to the kit procedure. DNA isolated from patient samples was measured by using a spectrophotometer (ND$2000, \mathrm{ROCHE})$ and maintained in the refrigerator with $-80^{\circ} \mathrm{C}$. Amplification of urea $\mathrm{A}$ and $\mathrm{B}$ genes were done by using the newly designed primers that were shown in Table 1. For the PCR experiments H. pylori G27 strain DNA was used as a positive control. Amplification reactions were carried out in a PCR tube with a total volume of 20 $\mu \mathrm{l}$. All PCR assay mixture ingredients and conditions are shown in Tables 2 and 3. By using an agarose gel electrophoresis the amplified PCR products were loaded to the gels and stained with a nucleic acid dye (SYBR Gold - In vitro gene). To confirm the urease primers specificity positive and negative controls were used. 
Table 1. Sequence of Multiplex urease PCR primers for the urea A and $B$ genes amplification

\begin{tabular}{|c|c|c|c|c|}
\hline $\begin{array}{l}\text { Amplified } \\
\text { DNA } \\
\text { region(s) }\end{array}$ & $\begin{array}{l}\text { Primer } \\
\text { Name }\end{array}$ & $\begin{array}{c}\text { Sequence }\left(5^{\prime} \rightarrow 3^{\prime}\right) \text { PCR Product Size } \\
(\mathrm{bp})\end{array}$ & $\begin{array}{c}\text { PCR } \\
\text { Product } \\
\text { Size } \\
\text { (bp) }\end{array}$ & $\begin{array}{l}\text { Refe- } \\
\text { rences }\end{array}$ \\
\hline \multirow{2}{*}{ Urease A } & ure $A-F$ & TGATGGGACCAACTCGTAACCGT & \multirow{2}{*}{244} & \multirow{4}{*}{6} \\
\hline & ure $A-R$ & CGCAATGTCTAAGCGTTTGCCGAA & & \\
\hline \multirow{2}{*}{ Urease B } & ure B-F & AGTAGCCCGGTAGAACACAACATCCT & \multirow{2}{*}{645} & \\
\hline & ure $B-R$ & ATGCCTTTGTCATAAGCCGCTTGG & & \\
\hline
\end{tabular}

\section{Table 2. Components of Multiplex Urease PCR assay}

\begin{tabular}{|l|l|}
\hline \multicolumn{1}{|c|}{ Component } & Amount \\
\hline DreamTaq Buffer 10X (including $\left.20 \mathrm{mM} \mathrm{MgCl}_{2}\right)$, & $2,5 \mu \mathrm{l}$ \\
\hline dNTP $(200 \mu \mathrm{M})$ & $2,0 \mu \mathrm{l}$ \\
\hline Forward Primer $(20 \mu \mathrm{M})$ & $1 \mu \mathrm{l}$ \\
\hline Reverse Primer $(20 \mu \mathrm{M})$ & $1 \mu \mathrm{l}$ \\
\hline Dream Taq DNA polymerase enzyme $(0,65 \mathrm{U})$ & $0,69 \mu \mathrm{l}$ \\
\hline PCR Grade water & $18,81 \mu \mathrm{l}$ \\
\hline
\end{tabular}

\section{Table 3. Multiplex Urease PCR conditions}

\begin{tabular}{|l|l|}
\hline Temperature & Time \\
\hline $95^{\circ} \mathrm{C}$ & $3 \mathrm{~min}$. \\
\hline $95^{\circ} \mathrm{C}$ & $45 \mathrm{sec}$. \\
\hline $60^{\circ} \mathrm{C}$ & $45 \mathrm{sec} . \quad(45 \mathrm{cycles})$ \\
\hline $72^{\circ} \mathrm{C}$ & $2 \mathrm{~min}$. \\
\hline $72^{\circ} \mathrm{C}$ & $5 \mathrm{~min}$. \\
\hline $4^{\circ} \mathrm{C}$ & $\infty$ \\
\hline
\end{tabular}

\section{Statistical Analysis}

The sensitivity, specificity, accuracy, and predictive value ratio for $H$. pylori multiplex urease PCR test from stool samples were calculated by using MEDCALC statistical software (7).

\section{MAIN POINTS}

- For pediatric patients, it will be more practical to detect $H$. pylori infection from the stool sample with a multiplex urease PCR rather than a biopsy sample.

- Due to the comparison results with the H. pylori antigen test, the multiplex urease PCR test has $100 \%$ sensitivity with 65,52 specificity.

- The positive predictive value of the multiplex urease test from the stool sample is $72.22 \%$ and the test could detect negative samples with the $100 \%$ percentage. $81.82 \%$ is the accuracy of the test.

\section{RESULTS}

The results from 55 pediatric patients examined from 11.08.2017and 27.12.2018 by the multiplex urease PCR were assessed. The population consisted of 24 boys and 31 girls with a mean age of seven. Thirty-six patients (65\%) were found to be $H$. pylori-positive including nineteen boys $(50 \%)$ and nineteen girls ( $50 \%$ ) by $\mathrm{H}$. pylori multiplex urease PCR test. Fifteen ( $54 \%$ ) of the positive patients were in the 0-6 age range, eighteen (95\%) in the 7-12 age range, and three (38\%) in the 13-18 age range (Table 4).

Evaluation of $H$. pylori multiplex urease PCR test for stool sample test results compared with the $H$. pylori antigen test was shown in Table 5 . The test has $100 \%$ sensitivity with 65,52 specificity. $72.22 \%$ is the positive predictive value of the test and the test could detect negative samples with the $100 \%$ percentage. $81.82 \%$ is the accuracy of the test.

\begin{tabular}{|l|l|l|}
\hline \multicolumn{2}{|l|}{ Table 4. Characteristics of 55 pediatric patients. } \\
\hline & Number of patients & $\begin{array}{l}\text { Rate of H. pylori } \\
\text { Infection }\end{array}$ \\
\hline Total & 55 & $38(69 \%)$ \\
\hline Gender & & \\
\hline Male & 24 & $19(79 \%)$ \\
\hline Female & 31 & $19(61 \%)$ \\
\hline Age (Years) & & \\
\hline $0-6$ & 28 & $15(54 \%)$ \\
\hline $7-12$ & 19 & $18(95 \%)$ \\
\hline $13-18$ & 8 & $3(38 \%)$ \\
\hline
\end{tabular}

Table 5. H. pylori multiplex urease PCR test from stool samples test evaluation results

\begin{tabular}{|l|l|l|}
\hline Statistic & Value & $\begin{array}{l}95 \% \text { Confidence } \\
\text { Interval }\end{array}$ \\
\hline Sensitivity & $100 \%$ & $86.77 \%$ to $100 \%$ \\
\hline Specificity & $65.52 \%$ & $45.67 \%$ to $82.06 \%$ \\
\hline $\begin{array}{l}\text { Positive Predictive } \\
\text { Value }\end{array}$ & $72.22 \%$ & $61.15 \%$ to $81.11 \%$ \\
\hline $\begin{array}{l}\text { Negative Predictive } \\
\text { Value }\end{array}$ & $100.00 \%$ & $86.77 \%$ to $100 \%$ \\
\hline
\end{tabular}




\section{DISCUSSION}

H. pylori cause the most important bacterial infections involved with about $50 \%$ of the population worldwide. This pathogenic bacteria poses a significant health burden, especially in developing countries. Approximately, $10 \%$ of children and $80 \%$ of adults are infected with this pathogenic bacteria in developing countries. Successful eradication of infection reduces the rate of recurrence, but if it is not treated, it will continue for lifelong (8).

Many different methods were developed to diagnose $\mathrm{H}$. pylori infection and mainly these developed methods could be classified as invasive and non-invasive. The most useful invasive method is endoscopy for the detection of this pathogenic bacteria. However, it is not easy to apply endoscopy to all patients like pediatric patients and especially infants.

For the detection of $H$. pylori infection in children, noninvasive diagnostic methods have been used despite their relatively low diagnostic accuracy since invasive investigations like endoscopy are difficult to apply to infants or young children. To be more practical non-invasive tests can be applied to pediatric patients by the analysis of stool, urine, and saliva as bodily materials. Especially the stool sample rather than a biopsy sample as a non-invasive method detection material will be more practical to detect $H$. pylori infection from pediatric patients (9).

As a rapid molecular technique compared to base on culture, polymerase chain reaction (PCR) could be used to diagnose H. pylori DNA in stool and saliva samples as an non invasive method. With the help of the PCR, it is possible to detect microorganisms that are present in low numbers and also slow-growing with high sensitivity and specificity. Although culture is defined as the most specific and preferred method to detect $H$. pylori, it is not easy to cultivate this pathogenic microorganism from stool and saliva samples. Thus, compared with bacterial cultivation, the PCR method seems to be a more attractive molecular technique chosen to diagnose this pathogenic bacterial infection for fecal and saliva samples (10-11).

In our previous study, we developed a multiplex PCR for H. pylori ure A and ure B genes that could detect bacterial infection by using biopsy samples. The performance of our multiplex urease PCR for biopsy specimen was shown by comparing its results with RUT and histopathology. Cohen's kappa coefficient value comparison results indicated a moderate agreement for histopathological staining and rapid urease test results. Furthermore, rapid urease test and histopathological staining results were negative for some samples that were indicated as positive by the multiplex urease PCR (6).

Herein, we evaluate the performance of our multiplex urease PCR assay to diagnose $H$. pylori infection from the pediatric patient stool sample, and also this retrospective study was showed the $H$. pylori infection rate in the pediatric patients. The positive predictive value of multiplex urease PCR was found $72,22 \%$ with $100 \%$ sensitivity and $65,52 \%$ specificity. Also, the accuracy of the test was found as $81,82 \%$. The main reasons behind these results could be the PCR inhibitors are frequent in stool samples and can lead to false-negative PCR results by decreasing the accuracy of the test.

Our results indicate that approximately $65 \%$ of pediatric patients with suspicion of $H$. pylori are found positive in clinical examination in one year. This rate shows that $H$. pylori, which is still an important infection factor in the world, continues in our country In many patients, vomiting, abdominal pain, nausea, and gas problems appear to be common problems.

In conclusion, several different invasives and non-invasive diagnostic techniques are currently available to diagnose H. pylori infection. Especially, for pediatric patients, noninvasive test methods are more preferable. PCR assays are increasingly used molecular methods as a standard to diagnose and characterize microorganisms. However, inhibitors found in the analyzed sample may affect the PCR result and cause false-positive or false-negative results. New techniques like a bead or spin column systems could be used during the DNA isolation and a PCR clean-up kit could be used after PCR to overcome these problems.

Our results indicated that the currency of $H$. pylori infection is still high in pediatric patients in our country as the world. The detection of $H$. pylori infection in stool sample multiplex urease PCR could be quite easy especially for pediatric patients. However, many more studies with more samples are needed to evaluate the accuracy of multiplex urease PCR for a stool sample. Using the multiplex urease PCR test as a non-invasive method for the diagnosis of $H$. pylori will be very effective especially for the pediatric patient group that endoscopy applications are difficult. 


\section{References}

1. Stewart BW, Wild CP. Stomach cancer. International Agency for Research on Cancer World cancer report 2014; Lyon, France

2. Frenck RW Jr., Clemens J. Helicobacter in the developing world. Microbes and infection. Institut Pasteur. 2003;5(8):705-13. Epub 2003/06/20. pmid:12814771.

3. de Brito BB, da Silva FAF, Soares AS, Pereira VA, Santos MLC, Sampaio MM, Neves PHM, de Melo FF. Pathogenesis and clinical management of Helicobacter pylori gastric infection. World J Gastroenterol. 2019;7;25(37):5578-5589. doi: 10.3748/wjg.v25.i37.5578. PMID: 31602159; PMCID: PMC6785516.

4. Fischbach W, Malfertheiner P. Helicobacter Pylori Infection. Dtsch Arztebl Int. 2018;115(25):429-436. doi:10.3238/arztebl.2018.0429

5. Can F, Karahan C, Dolapci I, et al. H. Urease activity and urea gene sequencing of coccoid forms of $\mathrm{H}$. pylori induced by different factors. Curr Microbiol. 2008;56(2):150-155. doi:10.1007/s00284-007-9047-y.

6. Okullu SO, Kocagöz T, Tiftikçi A, et al. A Multiplex-Urease PCR Assay for Detection of Helicobacter pylori Infection Directly from Gastric Biopsy Specimens and Comparison of Multiplex-Urease PCR Results with Rapid Urease Test and Histopathology. Clin Microbiol. 2017;6: 279. doi:10.4172/2327-5073.1000279

7. https://www.medcalc.org/calc/diagnostic_test.php

8. Hooi JKY, LaiWY, Ng WK, et al. Global Prevalence of Helicobacter pylori Infection: Systematic.Review and Meta-Analysis. Gastroenterology. 2017;153(2):420-429. doi:10.1053/j.gastro.2017.04.022

9. Yang HR. Updates on the Diagnosis of Helicobacter pylori Infection in Children: What Are the Differences between Adults and Children?. Pediatr Gastroenterol Hepatol Nutr. 2016;19(2):96-103. doi:10.5223/ pghn.2016.19.2.96

10. Pohl D, Keller PM, Bordier V, et al. Review of current diagnostic methods and advances in Helicobacter pylori diagnostics in the era of next generation sequencing. World J Gastroenterol. 2019;25(32):4629-4660. doi:10.3748/wjg.v25.i32.4629

11. Patel SK, Pratap CB, Jain AK, et al. Diagnosis of Helicobacter pylori: what should be the gold standard?. World J Gastroenterol. 2014;20(36):12847-12859. doi:10.3748/wjg.v20.i36.12847 